\title{
CULTURAL ENCOUNTERS IN MODERN PRODUCTIONS OF GREEK TRAGEDY
}

\section{S. E. WILMER}

\begin{abstract}
The exiled character in need of asylum is a recurrent theme in ancient Greek tragedy. In many of these plays, we see uprooted and homeless persons seeking sanctuary, and for the ancient Greeks, hospitality was an important issue. Many of these plays have been updated to comment on the current social and political conditions of refugees. In Hamburg a group of 80 asylum seekers who came to Germany via Lampedusa found refuge in St Pauli church, and it was there that Nicholas Stemann presented a first reading of Elfriede Jelinkek's play D ie Schutzbefohlenen in September 2013. Recently right-wing groups have mounted weekly marches through Dresden to call for a halt to immigration, and these have been contested by simultaneous counter-demonstrations in favour of immigrants and refugees. In this paper I will consider several adaptations of Greek tragedy that highlight cultural encounters between the local population and those arriving from abroad who are looking for asylum. In particular I will examine Stemann's production that has been running at the Thalia Theater in Hamburg since September 2014, and features asylum seekers from Lampedusa on stage who beg the audience for the right to remain in Germany.
\end{abstract}

Keywords: D ie Schutzbefohlenen, refugees, Jelinek, Stemann, T he Suppliants

The exiled character in need of asylum is a recurrent theme in ancient Greek tragedy. For example, Medea, Orestes, the Children of Herakles, Oedipus in 0 edipus at Colonus, and the daughters of Danaos in Aeschylus' The Suppliants all seek asylum. In Aeschylus' The Suppliants, the fifty daughters of Danaos arrive in Argos from overseas, fleeing from the sons of Aegyptus, and ask King Pelasgos for protection. Likewise, the Children of Herakles seek safety in Athens from Eurystheus who is determined to kill them. After Creon tells her that she must leave Corinth immediately, Medea, who refers to herself as "apolis" or stateless, persuades Aegeus to provide her with sanctuary in Athens before she wreaks vengeance on Jason. In 0 edipus at Colonus, Oedipus is a stateless person, having been exiled from Thebes. Guided by his daughter Antigone, he asks King Theseus for sanctuary in the outskirts of Athens, and succeeds in finding a final resting place. It is interesting that in this case he provides a kind of sanctuary for Athens in return for being granted one; by allowing Oedipus to be buried in Colonus, Theseus ensures that Athens will be protected in the future. The play thereby emphasizes the potential benefit of looking after asylum-seekers.

In these plays, we see uprooted and homeless 
persons seeking sanctuary, and the obligation of hospitality or xenia is revealed as an important responsibility for the ancient Athenians. ${ }^{1}$ Thus, the problem of asylum is an ancient one, both in the theatre and in real life. Some of these plays have been updated in recent years to comment on the plight of today's refugees and often to reflect on the concept of hospitality, a social duty, which both Emmanuel Levinas and Jacques Derrida considered to be fundamental to ethics. ${ }^{2}$

In this paper, I will show how German theatres responded to the current immigration crisis by presenting productions about refugees and by becoming politically active as institutions. I will examine the production of Elfriede Jelinek's D ie Schutzbefohlenen (directed by Nicolas Stemann) as an emblematic case study of a play that used an ancient Greek drama as a pretext to comment on the crisis, calling attention to the tension between law and justice, between citizenship and human rights, and between finite and infinite hospitality.

\section{OTHER ADAPTATIONS OF PLAYS ABOUT REFUGEES}

Before considering this specific case study, I'll look briefly at some other adaptations of Greek tragedies that deal with refugees. Like D ie Schutzbefohlenen, many adaptations use the original text as a starting point, retaining some of the structural elements of the narrative and perhaps the character's names, but often straying so far from the original that it seems like a completely new script. For example, the plight of Antigone can serve as a useful means for calling attention to the position of the stateless person, and several dramatists have used this character as a starting point for an original script focusing on the socially excluded or the Other in society. The philosopher Hegel regarded Antigone as an "internal enemy", 3 opposing the legitimate role of the state, and in that sense she can be regarded as a stateless person. An example of this can be seen in the emotionally charged versions of A ntigone, such as the very much transformed A ntígona Furiosa by Griselda Gambaro, featured in the Argentinian theatre in the 1970s and 1980s, when opponents of the state were disappearing and mothers were parading in the Plaza de Mayo, calling on the state to divulge the whereabouts of their disappeared children.

In Janusz Glowacki's A ntigone in N ew York (staged at the Arena Stage 4 in Washington, D.C. in 1993), Anita, the Antigone figure, tries to reclaim the body of Paulie, her dead lover, who has been removed by the authorities to be buried in an unmarked grave. A homeless immigrant from Puerto Rico, Anita wants to bury him in a Manhattan public park where she lives. As both a homeless person and an immigrant, her legal and ontological status is ill defined. Her friend Sasha tells her: 'We have to get indoors. When you live outdoors no one thinks you are a person' (72). Moreover, because it is dark when her friends retrieve the body and mistake another corpse for Paulie's, Anita ends up ironically burying someone else instead of her lover in the park. Eventually, the police close down the park, erecting a ten-foot high barbed wire fence around it, and rendering her status even more insecure. Anita hangs herself on the main gate of the park after trying unsuccessfully to climb over the fence to return to Paulie's grave. The authorities take her to be buried in an unmarked grave, sadly rejected by civil society. ${ }^{5}$

Likewise, Euripides' Medea has been adapted to address the lifestyle and circumstances of nomadic people. Marina Carr's By the Bog of Cats... (1998) transposed the play to the Irish midlands with the Medea character, represented by Hester Swane, a member of the ostracized Travelling Community. The Travelling Community in Ireland, like the Roma in other parts of Europe, adopt lifestyles that do not coincide with the private property obligations of the capitalist system. In order to maintain the rights of a citizen in the nation-state, one must provide an address, "a fixed abode". Having no "fixed abode" reduces one virtually to the status of the refugee. Thus, those who choose a nomadic lifestyle are frequently deprived of human rights by the exclusionary policies of governments and by the hostility of local residents. In Marina Carr's version, the structure of the ancient Greek play is retained but the 
names are changed and many new scenes, characters, and back stories are added so that it seems like a new play. Hester Swain, the Medea figure, is evicted from her home by her partner's father, Zavier Cassidy. But unlike in the original, there is no Aegeus character who will provide her with a place of exile. Threatened with social exclusion and the dispossession of her young daughter, she takes her own life as well as that of her child.

In the theatre season 2014-2015 Greek tragedies about refugees and their adaptations carried all the more resonance as the world was experiencing, according to António Guterres, the United Nations' High Commissioner for Refugees, "the highest levels of forced displacement in recorded history." "The increased number of refugees had been partially caused by the situation in Syria and Iraq with fifteen million people being displaced, of whom four million Syrians had been living in refugee camps in surrounding countries. Many of these had begun to lose hope that they would ever be able to return to their native land and looked to Europe as a possible home, with Greece alone receiving more than half a million people in 2015 , ten times as many as in the previous year, and with Germany suddenly opening its borders to them.

The problem of asylum, of course, was not a new issue in Europe, with demonstrations for and against immigration having occured in European countries for years. Right-wing activists in many countries continued to voice their opposition to immigration, especially in Central and Eastern Europe, France, the Netherlands, Denmark, and Britain. In Germany in 2014 and 2015, a group called Pegida (an acronym which stands for "Patriotic Europeans Against the Islamisation of the West") ${ }^{7}$ mounted weekly marches through Dresden against immigration. In addition, German refugee shelters were subjected to over 200 arson and other attacks. The German government initially took a hard line on refugees, requiring them, under the Dublin regulation, to return to the country that had been their first port of entry in Europe. In April 2015, a photo of a capsized boat of immigrants appeared on the front page of the newspaper D ie Zeit with a slogan that seemed to sum up the somewhat hostile but wavering attitude of the German government towards refugees: "We don't want them to drown. We don't want them to come here. What do we want to do?"8 In August 2015, Angela Merkel reversed the government policy by opening the borders to refugees (especially Syrians).

There were also protests and occupations of public spaces by the asylum seekers themselves, expressing their anger at the conditions in which they were forced to live. For example, in Austria a group of about sixty refugees (who had migrated from the Afghanistan-Pakistan border area and were being confined in the Traiskirchen camp outside Vienna) occupied the famous Votiv church in the middle of Vienna in the winter of 2012-13 and some of them went on hunger strike. In Germany, a large number of asylum seekers marched to Berlin from various cities around the country to occupy the central square at the Brandenburg Gate before being allowed to establish a tent community and inhabit a disused school amidst the immigrant community of Kreuzberg. In Hamburg, a group of about eighty asylum seekers, many of whom had come to Germany via Lampedusa, found refuge in St Pauli church. Protest camps were created in many other German cities, such as Dortmund and Munich, and riots sometimes erupted in the overcrowded refugee facilities, such as in Suhl in August 2015.

\section{THE ROLE OF THE GERMAN THEATRE COMMUNITY}

There was a strong pro-immigration movement in Germany that may also have influenced the change in government policy. One of the leaders in the campaign in Berlin to welcome refugees was Shermyn Langhoff, a Turkish immigrant who had founded the Theater at Ballhaus Naunynstrasse where she featured post-migrant theatre, and later became Intendant of the Maxim Gorki theatre, where she presented a series of productions featuring immigration. Moreover, when asylum seekers were being threatened with eviction from a school they were occupying in 
Kreuzberg in 2014, Langhoff offered housing to some of them at the Gorki and sent an appeal to the other major theatres in Berlin to help. She also sent an open letter (which was also signed by the major German theatre directors, choreographers, actors and musicians including Claus Peymann, Thomas Ostermeier, René Pollesch, Sacha Waltz, etc.) to the German government and others in authority to intercede on behalf of the asylum seekers. In November 2014, at the time of celebrating the twenty-fifth anniversary of the fall of the Berlin wall, the Gorki theatre was used as a rallying point for a controversial bus trip to Bulgaria organised by an activist group called "The Center for Political Beauty" who were protesting against the erection of a new wall in Bulgaria, on the Eastern border of the EU, to stop immigration.

A further factor was the number of proimmigration plays that appeared in the theatres' repertories. Perhaps the most noteworthy was Elfriede Jelinek's D ie Schutzbefohlenen. Nicolas Stemann, who was employed by the Thalia Theatre in Hamburg, held a first reading of Jelinek's play in September 2013 at St. Pauli church in Hamburg in front of a group of Lampedusa refugees who had been given sanctuary in the church. The play was then presented at the Theater der Welt festival in Mannheim and the Holland Festival in Amsterdam before finally opening at the Thalia Theatre in Hamburg in September 2014. It was then invited to open the prestigious Theatertreffen in Berlin in May 2015. The decision by the Theatertreffen in Berlin to invite Stemann's production to open its theatre festival was apparently taken on political as well as artistic grounds, notably as a result of the increasing importance given to the refugee question by the theatre community.

The Theatertreffen in 2015 (as well as the Theater der Welt in 2014) not only featured Jelinek's play but also hosted debates about refugees, and also commemorated the work of Rainer Fassbinder, whose 1970s film A ngst E ssen Seele A uf ('Fear E ats the Soul') depicts community discord when a German woman marries a Turkish immigrant. Also in the 2014-15 season, the Theater Bremen hosted a season called "In Transit" during which it organised over fifty events about refugees. Thus, the state and municipal-funded theatres and the theatre community played an important role in the ongoing debate about the conditions of and support for asylum seekers in Germany. Moreover, some of the major German theatres in Berlin including the Gorki, the Schaubühne, the Theater an der Parkaue, the Ballhaus Naunynstrasse, the GRIPS Theater, and the Deutsches Theater joined with other activist groups to form a coalition called "My Right is Your Right" and organised protests and demonstrations to influence German government policy that may have encouraged Merkel's change of heart.

Nevertheless, despite the large number of deaths and human tragedies (including over 3000 drownings in the Mediterranean, member countries of the European Union continued to disagree about the responsibility for housing new immigrants and asylum seekers. By contrast with Germany welcoming refugees in August 2015, various EU states were constructing new barriers to keep them out, such as Spain's heightened security border fence in Melilla, Bulgaria's 100 mile fence with Turkey, Hungary's fence along its borders with Serbia and Croatia, and Britain's enhanced Channel Tunnel defenses. Some countries such as Hungary closed their borders; others (such as Macedonia) announced states of emergency or prohibited specific kinds of immigrants (Slovakia and the Czech Republic announced that they would refuse to admit Muslims). In May 2015, the British government, in opposing a European Union quota system for receiving refugees, focussed on stopping the influx rather than on the welfare of the migrants, and proposed that the EU organise military attacks on the boats that were transporting them and use "all means to destroy the business model of the traffickers... deploying helicopter gunships to 'neutralise' identified traffickers' ships."' Later, the British government suggested military action in Syria as a way of addressing the issue (although 
the additional bombings of Syria by various countries at the time of writing this essay in October 2015 only seemed to exacerbate the flow of refugees). ${ }^{10}$

However, with the rapid increase of refugees arriving in Europe from the Middle East in the summer of 2015 and the horrifying images of their journeys appearing on television and in the newspapers every day, the issue of immigration was brought into everyone's living room. The outpouring of sympathy from ordinary citizens in various European countries in the aftermath of the pictures of a small Syrian boy washed up on a beach in Turkey, indicated that the issue had finally touched a nerve with the general public in Europe, with many people offering space in their homes and providing supplies. Government responses to the crisis vacillated on a daily basis in reaction to pressure from the public and civic leaders, as well as to demands from right-wing leaders to stop the flow of refugees, and with the calls from the European Commission President and the German Chancellor to share responsibility for the refugees across the EU.

\section{REFUGEES ON THE GERMAN STAGE: THE CHILDREN OF HERAKLES}

One particularly interesting aspect of Stemann's production of $\mathrm{D}$ ie Schutzbefohlenen was that it featured asylum seekers on the stage, so it is important to consider the nature of this unusual cultural encounter, namely the impact and affect on a theatre audience of a play about asylum seekers that is transformed into a performance with and by asylum seekers. Stemann's was not the first production of a Greek tragedy that included asylum seekers on the German stage. For example, Peter Sellars also featured asylum seekers in a production of $\mathrm{T}$ he $\mathrm{C}$ hildren of $\mathrm{H}$ erakles which was staged at the time of the American invasion of Iraq. In the original Greek play, the children of Herakles and Iolaus, their guardian, are in danger of being killed, and plead for sanctuary. In his touring production, which was reasonably faithful to the original Greek tragedy, Sellars included asylum seekers or refugees living in the local areas in which the play was staged. However, for most of the performance, the young refugees sat on stage as silent witnesses and symbolic presences while professional actors spoke and acted the lines of the play. Sellars premiered this production in the Ruhr Triennale in 2002 and performed it in various cities afterwards in Europe as well as the USA, usually accompanied by a panel discussion as a way of engaging the audience in the debate over the issue. When Sellars performed it in Vienna in 2004, he presented it in the ceremonial hall of the Austrian Parliament in the presence of politicians with youths from the local refugee camp of Traiskirchen (outside Vienna) participating in the production. The participants on the panel prior to the performance included the hard-line Austrian Minister of the Interior Ernst Strasser. One reporter commented, "As is to be expected, Strasser entrenches behind a frozen smile and empty rhetoric ("We need to act on this"); the dialogue Sellars hoped to encourage does not happen. After the panel discussion, [actors] in uniforms of the U.S. Army declaim Euripides's text in a highly melodramatic manner, while Strasser sits in the auditorium passing his time writing text messages. The children of Herakles (silent parts) are embodied by young people from Traiskirchen. The audience is probably moved most by the fact that these actors have to return to the camp after the performance; that way the event may convey more [aspects of] the political reality [of the refugees] than it intended."11 A theatre critic responded, "[O]ne quickly sees what Sellars is getting at: it has to do with the laws of hospitality; in the conditions of ethics and law; in homelessness as a dire and fundamental state of being; and in 'audiatur et altera pars' ('listen to the other side') - listening to the weak 'other' of power, i.e. those who do not have the means to make their voices heard. Peter Sellars $[. .$.$] wants to give a stage and a voice to$ those who suffer most from the wealth gap and from globalization."12

\section{DIE SCHUTZBEFOHLENEN}

Elfriede Jelinek based her play D ie Schutzbefohlenen on Aeschylus' The Suppliants in which fifty women, who describe themselves as "the dark race", have 
crossed the Mediterranean from Egypt and arrive in Argos to ask for asylum from fifty men, the sons of King Aegyptus, who have been chasing them. Pelasgos, the King of Argos, after deliberating over the consequences of protecting them and asking his subjects' approval, agrees to shelter them. And so the tragedy ends happily, but with the ongoing fear of a possible attack. Jelinek uses the original Greek play as little more than a pretext for her version, which aims to address the current refugee crisis. Little remains of the original other than some intertextual links and allusions and the representation of vulnerable and powerless immigrants coming to a foreign land and asking for asylum. Jelinek relates the Greek tragedy to the plight of the refugees who had arrived from the Pakistan/Afghanistan border and had been detained in the Traiskirschen camp outside of Vienna. In the winter of 201213, they marched to Vienna and occupied the Votiv Church, demanding improved conditions such as the right to work and for their children to attend school, and some of them went on hunger strike. Like the women in The Suppliants, who plead, "Please help us; our feet have stepped onto your shores but where do we go from here?" Jelinek's play depicts the refugees seeking asylum from the Austrian government and indicating the threat to their lives and the hazards of returning home:

"We came on our own, to your church, a train of supplicants, please help us, God, please help us, we set foot on your shore, our foot also stepped on quite different shores, when it was lucky, but how will it go from here? The sea almost destroyed us, the mountains almost destroyed us, now we are in the church, tomorrow we will be in the monastery... but where will we be the day after tomorrow and after that?"13

Jelinek's version is not structured like the original ancient Greek text and has no characters or divisions of roles. It reads like a long rambling monologue or like a choral diatribe (sometimes in the first person singular and sometimes in the first person plural), heavily nuanced with classical references and current political issues, a postmodern bricolage of images. The text is quite playful, parodying governmental and popular attitudes about immigration and ethnicity, and calling attention to Austrian political problems such as the unequal treatment of immigrants. For example, it comments on Boris Yeltsin's daughter and the famous opera singer Anna Netrebko both being granted citizenship with little fuss while asylum seekers have to undergo a lengthy ordeal of bureaucratic paperwork and documentation in a foreign language. It also refers to the dangers for specific refugees who have fled from war-torn countries and whose families have been slaughtered, and the difficulty of providing evidence to the Austrian authorities that will convince them that they require protection. Jelinek's text also plays with the role of the church authorities and their relationship with government authorities, and mixes these with ancient Greek gods who can decide their fortune. Likewise, it conflates images of church sanctuary with national asylum. It also interpolates other ancient Greek references and Aeschylean images into the text such as the Io and Europa myths, with many playful and pointed allusions to cows and gadflies. The refugees compare themselves to Io, as they are treated as less than human, "half-human, not human at all." 14

The play text also parodies an Austrian government document welcoming foreigners called "Coexistence in Austria", which states that "everyone is equal in dignity," and that urges foreigners to adopt the Austrian values of freedom and democracy (which also resound as European values). The play contrasts these values with the conditions of the refugees and, among other things, comments on a passage that provides an analogy about Austrians swimming competitively and appreciating each other's efforts. The play text wryly comments, "What's with swimming? A neck-to neck race? So that we can express our mutual respect afterwards?...Why do we have to get into the water for that? Yes, some of us are getting out of the water, where, accidentally, they did not starve to death, die of thirst or drown. But they don't want to get back 
into it."15 The title, D ie Schutzbefohlenen, is somewhat subversive in that it means "those who are under protection or control", rather than "those seeking protection". ${ }^{16}$ Thus its meaning is ambivalent as to whether it implies that the government is protecting the refugees or simply controlling them.

As in Heiner Müller's play D espoiled Shore M edeamaterial Landscape with A rgonauts, which is a meandering monologue interlinking personal and political concerns with the figure of Medea and contains no stage directions, Jelinek's text gives little indication as to how it should be directed and contains no distinction of roles that individual actors might play. She leaves it to the theatre director to decide how to allocate speeches and create characters on stage. While Stemann's appears to have been the first stage version of the play, it was shortly thereafter directed in very different ways in at least two other productions, one by Mirko Borscht at the Theater Bremen in 2014 that was conceived as an attack on local politics and another by Michael Thalheimer at the Burg Theater in Vienna in 2015 that was set in a watery landscape and presented as a choral play with a masked chorus.

\section{STEMANN'S PRODUCTION OF DIE SCHUTZBEFOHLENEN ${ }^{17}$}

As the audience enter the Thalia Theater for Stemann's production, they see actors on a mostly bare stage acting as journalists interviewing some Lampedusa refugees about their ordeal in coming to Germany and their current vulnerable status. Their faces are projected onto a back screen as they speak and beneath this a series of numbers in the thousands can be seen that keep getting larger during the performance, indicating something sinister to do with the fate of refugees. Then, three white German actors with scripts in their hands advance towards the auditorium and begin to read the Jelinek text: "We are alive. We are alive. The main thing is we live and it hardly is more than that after leaving the sacred homeland. No one looks down with mercy at our train, but everyone looks down on us. We fled, not convicted by any court in the world, convicted by all, there and here."18

As the performance progesses, it incorporates musical numbers that add a humorous touch to counterpoint the harrowing images projected on the back screen of refugees struggling to survive on perilous Mediterranean voyages, dead bodies lying in rows on beaches, and children's coffins decorated with teddy bears. The production cleverly conflates the occupation of the church in Vienna with the situation of the asylum seekers who received sanctuary in a church in Hamburg after a disastrous journey from Libya. This is reemphasized by a huge crucifix descending onto centre stage that resonates with the refugees' experiences in gaining kirchenasyl, or asylum in a church, as a temporary measure. The performance offers an opportunity for the refugees to address the audience and state their need for asylum, raising awareness amongst the audience of the individual plight and vulnerability of refugees in a more direct way than the media can. As in Levinas's discussion of the ethics of hospitality, this encounter compels an affective and ethical response from the audience. Thus, the production evokes a sense of moral responsibility for those on the stage who are not just actors but people who do not have the right to remain in the country and could be deported at any time.

The question of who can speak for or on behalf of the refugees is raised repeatedly throughout the performance. Stemann felt uneasy about the permanent company of white German actors at the Thalia Theater representing asylum seekers. He wanted the refugees to be able to represent themselves. And so he developed a kind of compromise concerning who and what gets represented, with the actors and the refugees alternatively representing asylum seekers. While most of Jelinek's text is performed by the white German actors employed by the Thalia Theater, often acting with the script in their hands as if to emphasize that they are actors representing rather than enacting refugees, the actual asylum seekers appear and reappear many times on stage during the performance, both as witnesses and as symbolic presences. The white German actors do not stay in character as refugees but step in and 
out of their roles. Sometimes, they act as though they are speaking the lines of refugees and at other times they speak as actors questioning the roles that they are playing, or take on the roles of German or Austrian citizens questioning the immigration of foreigners. The actors also voice the attitudes of certain Germans or Austrians to A usländer, or foreigners: "And how come he, this foreigner, gets to sit in the subway and I don't [...]. Well, I will push him off the platform, at the next opportunity [...]" Stemann further destabilizes characterisation, identity and gender identification by the use of cross-dressing, desubjectivation, and cross-racialization with, at one point, a white actor in black face, a black actor in white face, another black actor in yellow face, and another white actor in red face. This creates a critical distance that allows the audience the space to become politically engaged.

Stemann's production makes visible those who are normally invisible in society and provides them with the opportunity to confront the audience with stories of their actual day-to-day suffering. Surrounded by a group of male refugees, one tells the audience about their coming from Lampedusa:

"We are Lampedusa. We were immigrant workers in Libya When the war started in Libya, we escaped through the sea to Italy because that was the only way to save our lives. Many people of us were not able to survive as we did. After two years in Italy, Italian authorities kicked us from our various camps without giving us integration. This is why we came to Hamburg."

The others around him join in, "We are here. We will fight. For freedom of movement is everybody's right."

The German actors discuss the situation of being illegal in Austria (and Germany) and living with the constant threat of deportation, and this connects with the actual presence of the asylum seekers on stage. By law the asylum seekers were not allowed to be employed in Germany when the play opened in September 2014. ${ }^{19}$ Consequently, most of the twenty-eight refugees on stage were not only inhabiting a liminal space of uncertainty as to whether they could remain in the country, but also they were walking a legal tightrope with a state theatre engaging them in a performance and paying them an allowance - an act that could also be considered illegal. ${ }^{20}$ The theatre was providing a place where the refugees not only were visible and had the chance to speak of their own conditions, but were also being paid for their work on stage, and it was uncertain whether this would help or hinder their longterm prospects, especially as they were taking a risk whenever they travelled with the company to other venues. At the end of the play, the male and female refugees once again take centre stage and advance on the audience stressing their bodily presence and the denial of their human rights. They relate how some of their fellow refugees have been deported and how one of the refugees who was in the show died in a parking lot in Amsterdam where he took shelter. One of the refugees announces,

"We are here tonight but we are not allowed to be. What you see here is illegal. The leader of this theatre didn't want us to be here because we don't have working papers. We are refugees. We play the part of refugees, not only in this show, [but] in our lives. We didn't choose this. We didn't write this script. Someone else wrote it. Someone like you. We came, but we are not here at all. Not here at all?"

And the other refugees on stage respond loudly, "We are here!", putting pressure on the audience again to consider their own responsibility.

This production as well as Jelinek's text uses various ironic and subversive tactics to question the current European attitudes and policies towards asylum seekers. They exhibit what Slavoj Zizek calls 'short circuits' in the political environment by confronting classic notions with their 'own hidden presuppositions' to reveal their 'disavowed truth' and thus 'illuminate a standard text or ideological formation, making it readable in a totally new way. ${ }^{21}$ Moreover, the production challenges claims and assumptions at the root of Western conceptions of citizenship and provokes 
audiences into thinking for themselves about the exclusive practices of citizenship and its limitation on human rights. ${ }^{22}$ The performance, through its radical adaptation of a Greek tragedy and the actual physical presence of refugees threatened with deportation, creates an imaginative space where the possibility for re-evaluation, reflection, and creation opens up. It not only questions where people should be allowed to live, but specifically what should happen to those refugees on stage and whether the state should act as host and provide for their guests.

\section{HOSPITALITY, JUSTICE AND HUMAN RIGHTS}

With regard to the question of hospitality, the production of D ie Schutzbefohlenen encourages the audience to wrestle with their conscience in deciding how to respond to what Levinas calls "the proximity of one to the other" who is in a state of "vulnerability". ${ }^{23}$ Faced with a group of refugees in their own city, the audience is put in the position of the King of Argos. The production evokes a sense of moral responsibility for those on the stage who gaze at the audience and demand a place to live. The performers are not just actors but people who do not have the right to remain in the country and could be deported at any time. The encounter compels an affective and ethical response. To what extent should the audience welcome these people who might cause fear or distrust in the local population because they look different, speak a different language, perhaps have a different religion, and different eating habits? Derrida suggests that "there is no face without welcome"24, but how far should that welcome be extended? Levinas argues that "to welcome the Other is to put in question my freedom." 25 Should these refugees be welcomed into their city, into their schools, into their homes? For example, Levinas questions the appropriate level of intersubjective responsibility; where to set the limits on extreme notions of hospitality whereby the host could effectively give up his/her place to the guest by giving everything to the Other?

The production also raises questions about the relationship between justice and the law. The actors on stage claim that "freedom of movement is everybody's right." However, the German (and European law) states that asylum seekers must stay in a particular place. Their possibilities to work are limited and they are given only a minimum of money to survive until their case is considered. But this can take years and so their lives can be put on hold for a long time. Rousseau's notion that everyone should have the right to choose where they want to live and to which nation they want to belong is obviously not applicable as nations maintain barriers against migration and restrict the ability to attain citizenship.

Giorgio Agamben points out, "If refugees (whose number has continued to grow in our century, to the point of including a significant part of humanity today) represent such a disquieting element in the order of the modern nation-state, this is above all because by breaking the continuity between man and citizen, nativity and nationality, they put the originary fiction of modern sovereignty in crisis." 26 Moreover, Hannah Arendt has argued that the individual who is deprived of citizenship has no human rights and so the UN Declaration on Human Rights can maintain little effectiveness when nations continue to exclude or deprive individuals of citizenship rights. ${ }^{27}$ While Derrida regards the concept of unconditional hospitality "an apolitical and irreceivable proposition," he claims that, "a politics that does not maintain a reference to this principle of unconditional hospitality is a politics that loses its reference to justice. It may retain its rights (which I again distinguish here from justice), the right to its rights, but it loses justice. Along with the right to speak of justice in any credible way." 28

D ie Schutzbefohlenen, through its adaptation of some of the themes in a Greek tragedy and featuring the actual physical presence of refugees threatened with deportation, creates an affective event and an imaginative space where the possibility for re-evaluation, reflection, and creation opens up. It not only questions where people should be allowed to live but specifically what should happen to those refugees on stage 
and whether the state (as well as members of the audience) should act as host and provide for those who come to their city. Many politicians have announced exclusionary methods such as John Howard, Prime Minister of Australia, who declared in an election speech about preventing boat people arriving from Asia, 'We will decide who comes to this country and the circumstances in which they come, ${ }^{29}$ and David Cameron, the British Prime Minister, who announced that his country would not "allow people to break into our country," 30 but would select them from refugee camps in Syria's neighbouring countries. By contrast, the audience of D ie Schutzbefohlenen is confronted with a fait accompli and offered an opportunity to intervene.

\section{CONCLUSION}

In conclusion, major German theatre institutions as well as theatre productions have been responding to the changing social dynamics and demographics in a post-migrant culture, and to the increasing immigration crisis. Some theatres such as Ballhaus Naunynstrasse and the Gorki Theatre have led the way in terms of hiring and casting post-migrant actors and challenging government policies. Others, such as the Thalia Theatre in Hamburg, have been taking risks by employing asylum seekers who were not allowed to be employed, allowing them to tell their own stories and express their claims for the right to remain, thereby forcing the audience to consider their own ethical responsibilities to the asylum seekers in the current humanitarian crisis.
Stemann's production makes visible those who are normally invisible in society and provides a voice to those who normally don't have one. In so doing it generates new experiences, interpretable by spectators in relation to their own memories and presuppositions, and encourages them to question their own place and identity in the nation state and their responsibility to those who are excluded. The performance also illuminates the mechanism of power behind social discourses on immigration, uncovering and exposing power structures and ideologies in the nation-state.

The physical embodiment on stage of asylum seekers who are uncertain whether they will be granted asylum adds a Levinasian resonance to the original play by Aeschylus. In Austria, the authorities succeeded in removing the refugees from their occupation of a central church in Vienna to a remote monastery where they became invisible and could be processed quietly, and many were imprisoned or deported. Perhaps by maintaining a physical presence on the Hamburg stage, the Lampedusa refugees were able to maintain their uneasy place in German society for a little longer. However, unlike The Suppliants by Aeschylus in which the daughters of Danaos are granted asylum, the production of $\mathrm{D}$ ie Schutzbefohlenen ends, not with a clear answer, but with a sense of uncertainty. It is not evident what will happen to the refugees on stage. And so the responsibility for this cultural encounter is thereby transferred and directed at the audience. Will you offer us hospitality and allow us to stay? 


\section{NOTES AND REFERENCES}

1. Robert Gorman refers to the "proud tradition of Asylum" in ancient Athens. Robert Gorman, "Poets, Playwrights, and the Politics of Eile and Asylum in Ancient Greece and Rome", International Journal of Refugee Law, Vol 6, no 3, p. 414, For a book-length discussion of the supplication process, see F. S. Naiden, A ncient Supplication, Oxford University Press, Oxford 2006.

2. See for example, Jacques Derrida and Anne Dufourmantelle, Of H ospitality, Rachel Bowlby, transl. Stanford University Press, Stanford, California 2000, p.151.

3. From her example, he generalised the position of women, who placed the interests of the family before the needs of the state, as "the everlasting irony [in the life] of the community." G.W.F. Hegel, Phenomenology of the Spirit. A.V. Miller, transl. Clarendon Press, Oxford 1977, p. 288.

4. It was also staged in various parts of Europe and at the Off-Broadway Vineyard Theatre in 1996 and translated into more than twenty languages.

5. For a discussion of this play, see Kott 2008.

6. António Guterres, United Nations High Commissioner for Refugees. Opening remarks at the 66th session of the Executive Committee of the High Commissioner's Programme. Geneva, 5 October 2015 Press Releases, 5 October 2015, http://www.unhcr.org/cgi$\mathrm{bin} /$ texis $/ \mathrm{vtx} /$ search?page $=$ search $\&$ docid $=561227536$ \&query $=$ refugees $\% 20$ october $\% 202015$, accessed 30 October 2015.

7. Or in German, Patriotische Europäer gegen die Islamisierung des Abendlandes.

8. D ie Z eit, 23 April 2015.

9. Ian Traynor, "EU draws up plans for military attacks on Libya targets to stop migrant boats", The Guardian (London), 10 May 2015, http://www.theguardian.com/world/2015/may/10/eu -considers-military-attacks-on-targets-in-libya-to-stopmigrant-boats, Accessed 9 August 2015.

10. According to the UN, approximately 100,000 Syrians fled Syrian towns as a result of Russian bombing in October 2015. Suzanne Lynch, "Russian Attacks Lead to New Wave of Refugees from Syria". Irish Times, 28 October 2015, p. 1.

11. Wolfgang Kralicek "Traum und Trauma. Wenn ein Festival über die Ufer tritt: die Wiener Festwochen
2004,' Theater heute, Aug./Sep. 2004, p. 14.

http://www.kultiversum.de/Schauspiel-

Theaterheute/Wiener-Festwochen-Festivals.html, Katrin Wächter, transl.

12. Thomas Mießgang: "In weiter Ferne, so nah," Die Zeit, no. 23, 27 May 2004.

http://www.zeit.de/2004/23/ChildrenofHerakles, Katrin Wächter, transl.

13. Elfriede Jelinek, The Charges, Gitta Honegger, transl. London 2014, pp. 2-3.

14. Ibid., p. 51.

15. Ibid., p. 18.

16. The title has been translated by Gitta Honegger into English as "The Charges". Jelinek's title contrasts with Die Schützflehenden, the normal German translation of the title of the Aeschylean play, which means those begging for protection.

17. The discussion of the production is based on my having seen the second performance of the play at the Thalia Theater in Hamburg in September 2014. The theatre also very kindly gave me access to a video of the opening performance of the production.

18. Jelinek, op.cit., p. 2.

19. This law was later relaxed with asylum seekers allowed to work after three months, with the proviso that any job has to be offered to a German citizen first.

20. This was especially true when the asylum seekers traveled to other cities with the production.

21. Alexei Monroe, Interrogation Machine: L aibach and N SK, MIT Press, Cambridge, Massachusetts, 2005, pp. ix- $x$.

22. See S. E. Wilmer, "Playing with citizenship: NSK and Janez Janša”, Citizenship Studies, Volume 16, Issue 5-6, 2012, pp. 827-838.

23. Emmanuel Levinas, 0 therwise Than Being, Alphonso Lingus, transl., Martinus Nijhoff, The Hague 1981), p. 14.

24. Jacques Derrida, "From Adieu á Emmanel Levinas", Michael Naas and Pascale-Anne Brault, transl. p.22. https://www.ufmg.br/derrida/wpcontent/uploads/downloads/2010/05/02-DerridaJacques-From-Adieu-a-Emmanuel-Levinas.pdf, accessed 30 October 2015.

25. Quoted in ibid., p. 23.

26. Giorgio Agamben, H omo Sacer: Sovereign Power and Bare L ife, Daniel Heller-Roazen, transl., Stanford University Press, Stanford, California 1998, p. 131. 
27. Hannah Arendt, "We refugees.", The M enorah Journal, 31 (1), 1943, 69-77, pp. 1-2 (reprinted in H. Arendt, The Jewish W ritings, Schocken Books, New York, 2007.)

28. Jacques Derrida, N egotiations, Elizabeth Rottenberg, ed. and transl., Stanford University Press, Stanford 2002, p. 101.

29. "John Howard on Stopping Illegal Boats", https://www.youtube.com/watch?v=FrJ1 mMPpVuQ, accessed 30 October 2015.

30. Adam Withnall, "If these extraordinarily powerful images of a dead Syrian child washed up on a beach don't change Europe's attitude to refugees, what will?? Independent, 22 September 2015.

http://www.independent.co.uk/news/world/europe/i f-these-extraordinarily-powerful-images-of-a-deadsyrian-child-washed-up-on-a-beach-don-t-change10482757.html, accessed 30 October 2015.

S. E. Wilmer is Professor Emeritus and former Head of the School of Drama, Film and Music at Trinity College Dublin, and a Research Fellow at the International Research Center "Interweaving Performance Cultures" at the Freie Universität Berlin. Recent publications include ed. (with Audrone Zukauskaite) Resisting Biopolitics: Philosophical, Political and Performative Strategies (Routledge 2016), D eleuze and Beckett (Palgrave Macmillan 2015) and Interrogating A ntigone in Postmodern Philosophy and Criticism (Oxford UP, 2010). He recently edited a special number of N ordic Theatre Studies on "Theatre and the Nomadic Subject" (2015). 